\title{
AUTOMATION AND COMPUTER-INTEGRATED TECHNOLOGIES
}

UDC 620.179:534.6 (045)

DOI:10.18372/1990-5548.65.14986

\section{${ }^{1}$ S. F. Filonenko, \\ ${ }^{2}$ A. P. Stakhova \\ INTERRELATION ACOUSTIC ENERGY WITH THE COMPOSITE DEFORMATION SPEED AT ITS DESTRUCTION BY VON MISES CRITERION}

\author{
${ }^{1,2}$ Aerospace Faculty, National Aviation University, Kyiv, Ukraine \\ E-mails: ${ }^{1}$ fils0101@gmail.com, ${ }^{2}$ Angelik2003@ukr.net
}

\begin{abstract}
Results of theoretical researches of acoustic radiation energy interrelation with composition material deformation speed at its destruction by shear force with use von Mises criterion are considered. It is defined that to increase of deformation speed there is not a linear increase of acoustic radiation energy. Thus, increase of the acoustic emission signals maximum energy advances to increase of their total energy. It is shown that such increase of acoustic radiation energy is caused by increase of composition material process destruction speed. It is defined that the regularity of acoustic emission signals maximum and total energy change with increase deformation speed are well described by power functions.
\end{abstract}

Index Terms-Acoustic emission; acoustic radiation energy; criterion of destruction; energy statistical parameters; composite material.

\section{INTRODUCTION}

The Composition Materials (CM) possess high physical-mechanical characteristics. They are wide used at production of responsible parts, which work in the conditions of high temperatures and pressure, aggressive environments. To ensure the reliability of $\mathrm{CM}$ products, theoretical and experimental studies of the composites destruction processes using various methods are carried out. Studies are aimed at searching for criteria that allow predicting the limiting state of $\mathrm{CM}$ (determine the stage of approaching the complete composite destruction).

One of research methods of $\mathrm{CM}$ destruction processes is the method of acoustic emission (AE). Application the method is due to its high sensitivity and small inertia to the processes of materials deformation and fracture, including CM. AE method is a dynamic reflection the processes that occur in the structure of the material. Most studies of $\mathrm{CM}$ destruction processes using $\mathrm{AE}$ are experimental. The obtained empirical regularities of $\mathrm{AE}$ parameters changes have a limited application. This is due to the complexity of interpretation research results associated with complexity of the $\mathrm{AE}$ phenomenon - $\mathrm{AE}$ is reflection of processes in the material structure on micro and macro levels.

In theoretical studies, various models of $\mathrm{CM}$ destruction processes with attraction and $\mathrm{AE}$ method are used. The analysis of the results is aimed at predicting the $\mathrm{CM}$ destruction time. Thus not the processes of acoustic radiation formation and its parameters change, but the processes of accumulation events or $\mathrm{AE}$ energy are considered. These processes are considered closer to the CM complete destruction. At the same time, with existence the general concepts constructing models of $\mathrm{CM}$ destruction processes development for carrying out researches various criteria for destruction are used. One of such criteria is von Mises criterion. Determination of acoustic radiation parameters regularities change when using this destruction criterion and action of various factors is interest to development the methods of monitoring state and predicting CM destruction.

\section{STATEMENT OF THE TASK}

The purpose of article is research the influence of $\mathrm{CM}$ deformation speed on AE energy at composite destruction by shear force according to von Mises criterion.

For achievement the purpose of article the following problems were put:

- to simulate the acoustic radiation energy with increasing $\mathrm{CM}$ deformation speed and its destruction by von Mises criterion;

- to carry out data processing with determination the regularity of $\mathrm{AE}$ signals maximum and total energy change at increase of CM deformation speed and its destruction by von Mises criterion.

\section{REVIEW OF PUBLICATIONS}

Much attention in scientific literature is paid to theoretical and experimental studies of $\mathrm{CM}$ destruction processes. This is due to the need to 
develop methods for predicting the CM destruction. Theoretical studies are carried out using various concepts and models. One of models which is widely used at research of $\mathrm{CM}$ destruction processes is the fiber bundle model (FBM). The model has been offered in article [1] at research of textile materials destruction. Within many years the model developed and has found application at research of different materials [2] - [10].

According to the model, material is presented in the form of fibers (elements) bunch which have identical length. Elements destruction brittle and have linear elastic behavior until destruction. All elements have the same Young's modulus. The destruction of the elements occurs in a sequential manner upon reaching the value of their strength. The load at which the elements are destroyed is a random variable with a certain probability density and distribution function. When analyzing the material destruction process, certain rules are used to redistribute the applied load on the material remaining elements - local load sharing (when the element is destroyed, the load is redistributed to the nearest neighbors) and equal load sharing (when the element is destroyed, the load is redistributed to all remaining elements).

Most of the studies using the FBM are devoted to the CM destruction under stretching conditions [2] [10]. Thus the analysis of acoustic radiation is carried out [3], [4], [11]. However, when considering acoustic radiation, it is not the process of AE signal formation is analyzed. The analysis of energy accumulation process or the rate of $\mathrm{AE}$ events energy release is carried out. At the same time, the obtained relations characterize the destruction processes and acoustic radiation only in approximation to the complete material destruction, and at the time of destruction there is a gap in the studied functions.

In articles [12], [13], the FBM heterogeneous material destruction by shear force with a local and equal load sharing was considered. The regularities of equivalent stresses change for various fracture criteria with a linear input of deformation are considered. The analysis of patterns number remaining elements changes, as well as distributions of avalanche damage size caused by destruction of one element is carried out. In articles [14], [15] the FBM to the analysis of granulated material destruction process by shear force is considered. The analytical formulation of energy release rate during the material elements destruction is considered. The relationship between voltage surges and $\mathrm{AE}$ events, which is consistent with experimental data is shown. The received results as authors have noted can be used to predict the material destruction. It should be noted that at granular material destruction, the process of $\mathrm{AE}$ signal formation is also not considered.

In article [16] the FBM of CM destruction at action of shear force and $\mathrm{AE}$ signal is considered. Taking into account the basic provisions of FBM, rule (criterion) OR, and kinetics of $\mathrm{CM}$ destruction process, expressions for remaining elements number in time and $\mathrm{AE}$ signal are obtained. It is shown that dependence of remained elements number change in time has continuous nonlinear nature of decrease. Thus the continuous AE signal is formed. The $\mathrm{AE}$ signal is a pulse signal. It is characterized by the accelerated increase of the forward front and exponential reduction of the back front. It is shown that to increase of CM deformation speed there is an increase of AE signal amplitude and reduction of its duration. Theoretical researches of influence deformation speed on the $\mathrm{AE}$ energy parameters (power and energy) at KM destruction by shear force using criterion OR is considered in article [17]. It is defined that to increase of CM deformation speed there is not a linear increase of AE energy parameters. The obtained regularities are well described by power-law functions. It was also determined that a parameter which does not depend on the CM deformation speed is the area under envelope of AE signals amplitude. At the same time, when analyzing $\mathrm{CM}$ destruction process for the FBM, other criteria of destruction are also applied. One of such using criteria is von Mises criterion [12]. From the point of view CM diagnostic state, determination of acoustic energy relationship with the composite deformation speed during its destruction by von Mises criterion represents unconditional interest.

\section{RESULTS OF RESEARCHES}

At CM destruction by shear force using von Mises criterion for the case of two independent uniform distributions fracture thresholds with boundaries $[0,1]$ at linear load input, the equivalent stresses change is described by expression of the form [12]

$$
\sigma_{m}(t)=\alpha t \cdot 0.5\left[\left(2-2 \sqrt{\alpha t}+\alpha t^{\frac{3}{2}} \log \frac{1+\alpha t}{1-\alpha t}\right)-\alpha t^{\frac{3}{2}}\left(2 \sqrt{\frac{1-\sqrt{\alpha t}}{\alpha t}}+\log \frac{1+\sqrt{1-\sqrt{\alpha t}}}{1-\sqrt{1-\sqrt{\alpha t}}}\right)\right],
$$

where $\alpha$ is the deformation speed. 
Expression (1) is obtained provided that the Young's modulus and coefficient characterizing the material element dimensions are equal to 1 .

At such equivalent stresses change, the expression for the formed $\mathrm{AE}$ signal at $\mathrm{CM}$ destruction has the form [17]

$$
\begin{aligned}
& U(t)=U_{0} \mathrm{U}_{0}\left[\sigma_{m}(t)-\sigma\left(t_{0}\right)\right] \\
& \cdot e^{r\left[\sigma_{m}(t)-\sigma\left(t_{0}\right)\right]} \cdot e^{-\mathrm{v}_{0} \int_{t_{0}}^{t} e^{r\left[\sigma_{m}(t)-\sigma\left(t_{0}\right)\right]} d t},
\end{aligned}
$$

where $\sigma_{m}(t), \sigma\left(t_{0}\right)$ are respectively, equivalent stresses on the CM elements change in time and the threshold stresses corresponding to a time point $t_{0}$ of the CM beginning destruction; $U_{0}$ is the maximum possible displacement during the $\mathrm{CM}$ instant destruction, consisting of $N_{0}$ elements; $\mathrm{v}_{0}, r$ are constants depending on $\mathrm{CM}$ physicalmechanical characteristics.

According to the results of $\mathrm{AE}$ pulse signal amplitudes calculating, according to (2), we will calculate the signal energy by the expression

$$
E(t)=\Delta t_{k} \sum_{i} U_{i}^{2}\left(i \cdot \Delta t_{k}\right),
$$

where $i=0, \ldots, k$ is the number of $\mathrm{AE}$ signal amplitude value calculated for its duration; $\Delta t_{k}$ is the time interval between the calculated values of AE signal amplitudes ( $\Delta t_{k}=$ constant).

Let's carry out modeling of formed AE signal energy dependences change in time, according to (3), taking into account (1) and (2). We will carry out modeling in relative units. When modeling the value of speed of deformation $\alpha$ will be changed in the range of values from $\tilde{\alpha}=10$ to $\tilde{\alpha}=50$ with a step of increment 10. Thus the values of $v_{0}$ and $r$ are assumed to be equal: $\tilde{\mathrm{v}}_{0}=100000 ; \tilde{r}=100000$.

When modeling dependences of formed signal energy change we will consider that at $\tilde{\alpha}=10$ destruction CM begins at the time point $t_{0}$. To this time there corresponds the destruction threshold stress $\sigma_{0}$. The value of time $t_{0}$ is taken equal to $\tilde{t}_{0}=0.001$. According to calculations, expression (1), for time $t_{0}$ the destruction threshold stress $\sigma_{0}$ is equal $\tilde{\sigma}_{0}=0.008897277688462064$. When modeling of acoustic radiation energy we will consider that at other deformation speeds threshold stress $\tilde{\sigma}_{0}$ does not change.

Regularities of equivalent stresses change on the $\mathrm{CM}$ elements, according to (1), for the accepted deformation speeds are shown in Fig. 1.
According to the carried-out calculations (Fig. 1), at destruction threshold stress $\tilde{\sigma}_{0}=$ $=0.008897277688462064$ the times of $\mathrm{CM}$ beginning destruction for the accepted deformation speeds are make: for $\tilde{\alpha}=20-\tilde{t}_{0}=0.0005$; for $\tilde{\alpha}=30-\tilde{t}_{0}=0.00033$; for $\tilde{\alpha}=40-\tilde{t}_{0}=0.00025$; for $\tilde{\alpha}=50-\tilde{t}_{0}=0.0002$.

The results of calculations AE signals energy dependences change $\mathrm{AE}$ in relative units for the accepted modeling conditions are shown in Fig. 2. When plotting graphs on Fig. 2, the time is given by the time of beginning $\mathrm{CM}$ elements destruction for each deformation speed.

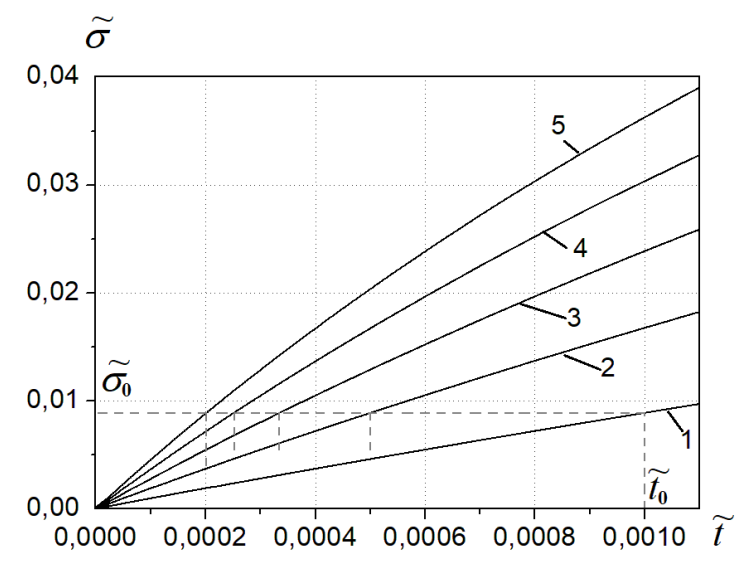

Fig. 1. Dependences of equivalent stresses change in time, according to (1), for various $\mathrm{CM}$ deformation speeds:

$$
\begin{gathered}
1-\tilde{\alpha}=10 ; 2-\tilde{\alpha}=20 ; 3-\tilde{\alpha}=30 ; 4-\tilde{\alpha}=40 ; \\
5-\tilde{\alpha}=50
\end{gathered}
$$

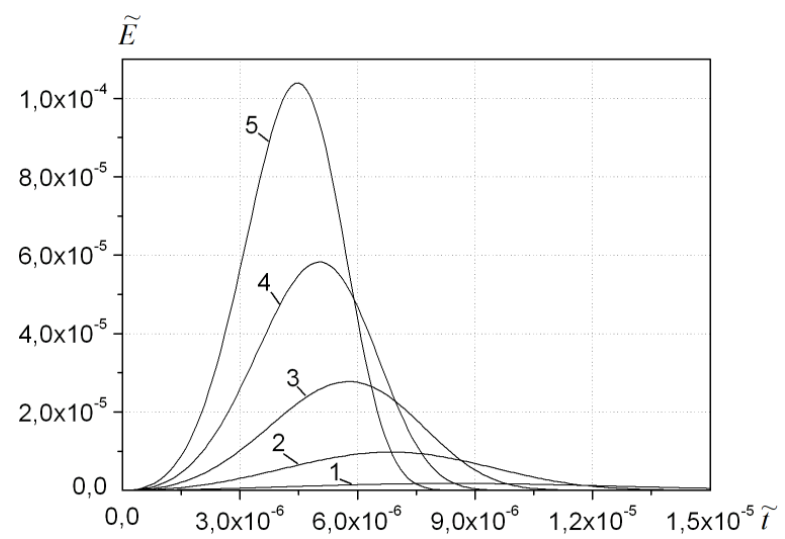

Fig. 2 Graphs of AE signals energy changes in time in relative units during the $\mathrm{CM}$ destruction by shear force. Deformation speed: $1-\tilde{\alpha}=10 ; 2-\tilde{\alpha}=20 ; 3-\tilde{\alpha}=30$;

$$
\begin{gathered}
4-\tilde{\alpha}=40 ; 5-\tilde{\alpha}=50 ; \tilde{\mathrm{v}}_{0}=100000, \tilde{r}=10000, \\
\tilde{\mathrm{v}}_{0}=0.008897277688462064
\end{gathered}
$$

From (Fig. 2) it is visible that with increase of $\mathrm{CM}$ deformation speed leads to increase of acoustic radiation energy. As demonstrate calculations, at increasing deformation speed in 2 times (from 
$\tilde{\alpha}=10$ to $\tilde{\alpha}=20$ ) the maximum and total energy of AE signal increase, accordingly, in 5.67 times and 3.74 times. At increasing deformation speed in 3 times (from $\tilde{\alpha}=10$ to $\tilde{\alpha}=30$ ) the maximum and total energy of AE signal increase, accordingly, in 16.11 times and 7.93 times. At further increasing deformation speed in 4 times (from $\tilde{\alpha}=10$ to $\tilde{\alpha}=40$ ) the maximum and total energy of AE signal increase, accordingly, in 33.83 times and 13.28 times. If the deformation speed increases in 5 time (from $\tilde{\alpha}=10$ to $\tilde{\alpha}=50$ ), the maximum and total energy of AE signal increase, accordingly, in 60.35 times and 19.79 times. Such increase of AE energy is caused by increase in speed and reduction the time of course CM destruction process. This is well observed in the dependences of the accumulated AE signals energy (Fig. 3).

From Figure 3 it is visible that with increase of $\mathrm{CM}$ deformation speed increase the steepness of accumulation AE signals energy curves is observed. When plotting graphs on Fig. 3, the time is given by the time of beginning $\mathrm{CM}$ elements destruction for each deformation speed.

The results processing of the obtained data in the form of dependences $\mathrm{AE}$ signals maximum and total energies changes in relative units at $\mathrm{CM}$ deformation speed increase are shown in Fig. 4.

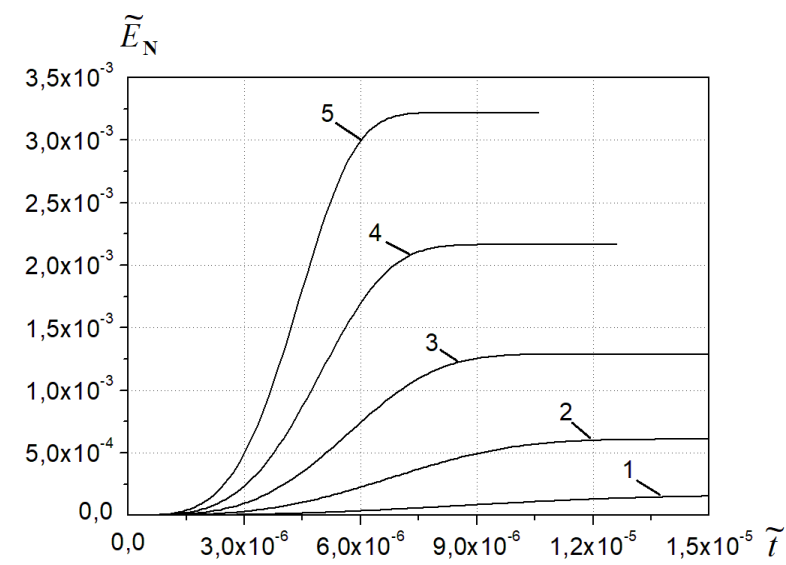

Fig. 3. Dependences of accumulation AE signals energy change in time in relative units during the $\mathrm{CM}$ destruction by shear force. Deformation speed: $1-\tilde{\alpha}=10$;

$2-\tilde{\alpha}=20 ; 3-\tilde{\alpha}=30 ; 4-\tilde{\alpha}=40 ; 5-\tilde{\alpha}=50 ;$ $\tilde{\mathrm{v}}_{0}=100000, \tilde{r}=10000, \tilde{\mathrm{v}}_{0}=0.008897277688462064$

From Figure 4 it is visible that dependences have not linear nature of increase. Approximation the data provided on Fig. 4a shows that dependence of $\mathrm{AE}$ signals maximum energy change on deformation speed during CM destruction is well described by a power-law function of the form

$$
\tilde{E}_{m}=a \tilde{\alpha}^{b},
$$

where $a, b$ are coefficients of approximating expression.

At description the dependence of Fig. 4a by expression (4) values of approximating expression coefficients $a$ and $b$ were equal: $a=4.1902 \cdot 10^{-9}$, $b=2.58647$. Thus determination coefficient $R^{2}$ make $R^{2}=0.99999$ and residual dispersion $S D^{2}$ make $S D^{2}=6.9787 \cdot 10^{-15}$. At approximating dependencies shown in Fig. 4a, the criterion for choosing the approximating expression (4) was the minimum of residual dispersion.

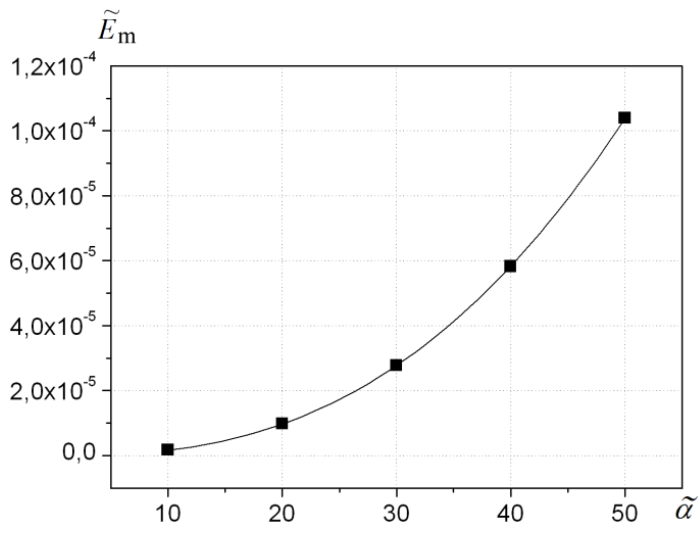

a)

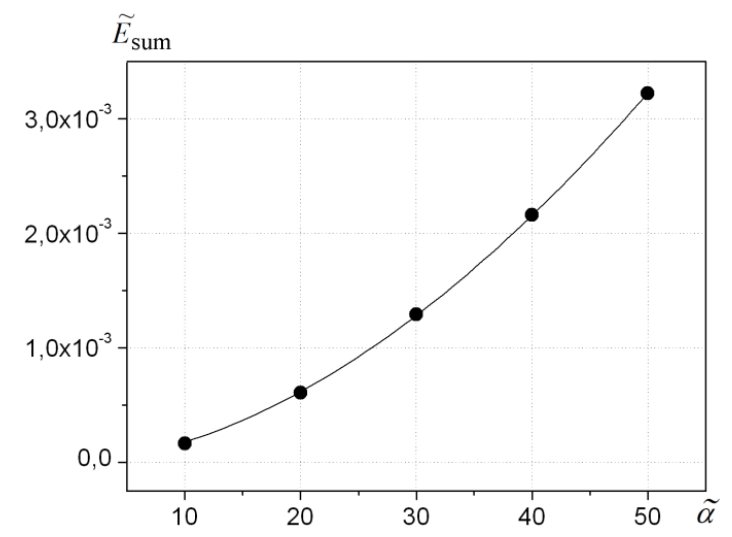

b)

Fig. 4. Dependences of AE signals maximum energy (a) and total energy (b) change from deformation speed in relative units at $\mathrm{CM}$ destruction by shear force

Approximation the data provided on Fig. 4b shows that dependence of AE signals total energy change on deformation speed during $\mathrm{CM}$ destruction is well described by a power-law function of the form

$$
\tilde{E}_{\text {sum }}=c \tilde{\alpha}^{d}
$$

where $c, d$ are coefficients of approximating expression.

At description the dependence of Fig. $4 \mathrm{~b}$ by expression (5) values of approximating expression 
coefficients $c$ and $d$ were equal: $c=2.7449 \cdot 10^{-6}$, $d=1.80696$. Thus determination coefficient $R^{2}$ make $R^{2}=0.99994$ and residual dispersion $S D^{2}$ make $S D^{2}=1.2311 \cdot 10^{-10}, \quad$ At approximating dependencies shown in Fig. $4 \mathrm{~b}$, the criterion for choosing the approximating expression (5) was the minimum of residual dispersion.

Results of researches show that increase of CM deformation speed at its destruction by shear force with using von Mises criterion leads to increase of acoustic radiation energy. Thus increase of $\mathrm{AE}$ maximum energy advances increase of $\mathrm{AE}$ total energy. Maximum and total energy of formed $\mathrm{AE}$ signals do not increase linearly. They are well described by power-law functions. Increase of acoustic radiation energy is caused by increase of $\mathrm{CM}$ destruction process speed. Regularities of $\mathrm{AE}$ signals maximum and total energy change can be used to develop methods of monitoring and predicting destruction products from $\mathrm{CM}$.

\section{CONCLUSION}

Results of modeling acoustic radiation energy at $\mathrm{CM}$ elements destruction by shear force with using von Mises criterion depending on deformation speed are considered. It is defined that to increase of deformation speed there is increase of acoustic radiation energy with reduction of $\mathrm{CM}$ destruction process time. Thus the maximum and total $\mathrm{AE}$ energy have nonlinear nature of increase. However, with increase the CM deformation speed increase of $\mathrm{AE}$ maximum energy advances increase of $\mathrm{AE}$ total energy. So at increase of deformation speed in 3 times the maximum and total energy of AE signal increase, accordingly, in 16.11 times and 7.93 times. At the same time, at increase of deformation speed in 5 times the maximum and total energy of $\mathrm{AE}$ signal increase, accordingly, in 60.35 times and 19.79 times. Such increase of acoustic radiation energy is due to increase the speed of development $\mathrm{CM}$ destruction process. It is shown that with increase of deformation speed the increase of $\mathrm{AE}$ signals accumulation energy speed is observed. Statistical data processing with approximation obtained regularities showed that dependences of $\mathrm{AE}$ maximum and total energy change are well described by power-law functions.

The results of the conducted researches can be used to develop methods monitoring and predicting destruction of various products from CM both at the production stage and at the operational stage. In the future, it will be interest to study the influence of $\mathrm{CM}$ physical-mechanical characteristics on fracture processes and $\mathrm{AE}$ signals amplitude-energy parameters.

\section{REFERENCES}

[1] F. T. Peirce, "Tensile tests for cotton yarns: "the weakest link" the-orems on the strength of long and of composite specimens," J. Textile Inst., vol. 17, pp. 355-368,

1926. https://doi.org/10.1080/19447027.1926.10599953

[2] S. Pradhan and B. K Chakrabarti, "Failure properties of fiber bundle models," Int. J. Modern Phys. B, vol. 17, pp. 5565-5581, 2003. https://doi.org/10.1142/S0217979203023264

[3] D. L. Turcotte, W. I. Newman, and R. Shcherbakov, "Micro and macroscopic models of rock fracture," Geophys. J. Int., vol. 152, pp. 718-728, 2003. https://doi.org/10.1046/j.1365-246X.2003.01884.x

[4] F. Bosia, N. Pugno, G. Lacidogna, and A. Carpinteri, "Mesoscopic modeling of Acoustic Emission through an energetic approach," International Journal of Solids and Structures, vol. 45, pp. 5856-5866, 2008. https://doi.org/10.1016/j.ijsolstr.2008.06.019

[5] S. Pradhan, A. Hansen, and B. K. Chakrabarti, "Failure processes in elastic fiber bundles", Rev. Modern Phys., vol. 82, pp. 499-555, 2010. https://doi.org/10.1103/RevModPhys.82.499

[6] Z. Danku and F. Kun, "Record breaking bursts in a fiber bundle model of creep Rupture," Frontiers in Physics, vol. 2, Article 8, 8 p., 2014. https://doi.org/10.3389/fphy.2014.00008

[7] A. Hader, Y. Boughaleb, I. Achik, and K. Sbiaai, "Failure kinetic and scaling behavior of the composite materials: Fiber Bundle Model with the local load-sharing rule (LLS)," Optical Materials, vol. $36, \quad$ pp. $3-7, \quad 2014$. https://doi.org/10.1016/j.optmat.2013.07.035

[8] M. Monterrubio-Velasco, F. Zúñiga, V. H. MárquezRamírez, and A. Figueroa-Soto, "Simulation of spatial and temporal properties of aftershocks by means of the fiber bundle model," J. Seismol, vol. 21, pp. 1623-1639, 2017. https://doi.org/10.1007/s10950-017-9687-8

[9] A. Capelli, I. Reiweger, P. Lehmann, and J. Schweizer, "Fiber-bundle model with timedependent healing mechanisms to simulate progressive failure of snow," Physical Review E, vol. 98, pp. $023002, \quad 2018$. https://doi.org/10.1103/PhysRevE.98.023002

[10] S. Pradhan, J. T. Kjellstadli, and A. Hansen, "Variation of Elastic Energy Shows Reliable Signal of Upcoming Catastrophic Failure," Frontiers in Physics, vol. 7, Article 106, 10 p., 2019. https://doi.org/10.3389/fphy.2019.00106

[11] A. R. Oskouei and M. Ahmadi, "Fracture Strength Distribution in E-Glass Fiber Using Acoustic Emission," Journal of Composite materials, vol. 44, no. 6, pp. 693-705, 2010. https://doi.org/10.1177/0021998309347963 
[12]F. Raischel, F. Kun, and H. J. Herrmann, "Simple beam model for the shear failure of interfaces," Phys. Rev.E, vol.72, no. 4, pp. 11, 2005. https://doi.org/10.1103/PhysRevE.72.046126

[13]F. Raischel, F. Kun, and H. J. Herrmann, "Local load sharing fiber bundles with a lower cutoff of strength disorder," Phys. Rev. E, vol. 74(2), no. 3, pp. 4, 2006. https://doi.org/10.1103/PhysRevE.74.035104

[14]G. Michlmayr, D. Or, and D. Cohen, "Fiber bundle models for stress release and energy bursts during granular shearing," Phys. Rev. E, vol. 86, no. 06, pp. 130 , $2012 b$. https://doi.org/10.1103/PhysRevE.86.061307

[15] G. Michlmayr, D. Or, and D. Cohen, "Shear-induced force fluctuations and acoustic emissions in granular material", Journal of Geophysical research: Solid
Earth, vol. 118, pp. 6086-6098, 2013. https://doi.org/10.1002/2012JB009987

[16] S. Filonenko, V. Kalita, and A. Kosmach, "Destruction of composite material by shear load and formation of acoustic radiation," Aviation, vol. 16, no. 1, pp. 5-13, 2012. https://doi.org/10.3846/16487788.2012.679831

[17]S. Filonenko and A. Stakhova, "Studying acoustic emission by fitting the destruction models of a composite according to the OR criterion and Mises criterion," Eastern-European Journal of Enterprise Technologies, no. 3/9 (105), pp. 39-45, 2020. https://doi.org/10.15587/1729-4061.2020.204820

Received August 28, 2020.

Filonenko Sergii. Doctor of Engineering Science. Professor.

Aerospace Faculty, National Aviation University, Kyiv, Ukraine.

Education: Kyiv Polytechnic Institute, Kyiv, Ukraine, (1977).

Research area: Diagnostics of technological processes, automatic diagnostic systems.

Publications: 316.

E-mail: fils0101@gmail.com

Stakhova Anzhelika. Candidate of Science (Engineering). Associate Professor.

Aerospace Faculty, National Aviation University, Kyiv, Ukraine.

Education: National Aviation University, Kyiv, Ukraine, (2005).

Research interests: Systems for technical diagnosing of friction units, the control and forecasting of the technical condition.

Publications: 56.

E-mail: Angelik2003@ukr.net

\section{С. Ф. Філоненко, А. П. Стахова. Взаємозв'язок акустичної енергії із швидкістю деформування композиту} при його руйнуванні за критерісм Мізеса

Розглянуто результати теоретичних досліджень взаємозв'язку енергії акустичного випромінювання із швидкістю деформування композиційного матеріалу при його руйнуванні поперечною силою 3 використанням критерію Мізеса. Визначено, що із зростанням швидкості деформування відбувається не лінійне зростання енергії акустичного випромінювання. При цьому зростання максимальної енергії сигналів акустичної емісії випереджає зростання їх сумарної енергії. Показано, що таке зростання енергії акустичного випромінювання обумовлено зростанням швидкості процесу руйнування композиційного матеріалу. Визначено, що закономірності зміни максимальної і сумарної енергії сигналів акустичної емісії іiі зростанням швидкості деформування добре описуються степеневими функціями.

Ключові слова: акустична емісія; енергія акустичного випромінювання; критерій руйнування; статистичні енергетичні параметри; композиційний матеріал.

Філоненко Сергій Федорович. Доктор технічних наук. Професор.

Аерокосмічний факультет, Національний авіаційний університет, Київ, Україна.

Освіта: Київський політехнічний інститут, Київ, Україна, (1977).

Напрям наукової діяльності: діагностика технологічних процесів, автоматизовані діагностичні системи.

Кількість публікацій: 316.

E-mail: fils0101@gmail.com

Стахова Анжеліка Петрівна. Кандидат технічних наук. Доцент.

Аерокосмічний факультет, Національний авіаційний університет, Київ, Україна.

Освіта: Національний авіаційний університет, Київ, Україна, (2005).

Напрямок наукової діяльності: системи технічного діагностування вузлів тертя, контроль і прогнозування технічного стану.

Кількість публікацій: 56.

E-mail: Angelik2003@ukr.net 
С. Ф. Филоненко, А. П. Стахова. Взаимосвязь акустической энергии со скоростью деформирования композита при его разрушении по критерию Мизеса

Рассмотрены результаты теоретических исследований взаимосвязи энергии акустического излучения со скоростью деформирования композиционного материала при его разрушении поперечной силой с использованием критерия Мизеса. Определено, что с возрастанием скорости деформирования происходит не линейное возрастание энергии акустического излучения. При этом возрастание максимальной энергии сигналов акустической эмиссии опережает возрастание их суммарной энергии. Показано, что такое возрастание энергии акустического излучения обусловлено возрастанием скорости процесса разрушения композиционного материала. Определено, что закономерности изменения максимальной и суммарной энергии сигналов акустической эмиссии с возрастанием скорости деформирования хорошо описываются степенными функциями. Ключевые слова: акустическая эмиссия, энергия акустического излучения, критерий разрушения, статистические энергетические параметры, композиционный материал.

Филоненко Сергей Федорович. Доктор технических наук. Профессор.

Аэрокосмический факультет, Национальный авиационный университет, Киев, Украина.

Образование: Киевский политехнический институт, Киев, Украина, (1977).

Направление научной деятельности: диагностика технологических процессов, автоматизированные диагностические системы.

Количество публикаций: 316.

E-mail: fils0101@gmail.com

Стахова Анжелика Петровна. Кандидат технических наук.

Аэрокосмический факультет, Национальный авиационный университет, Киев, Украина.

Образование: Национальный авиационный университет, Киев, Украина, (2005).

Направление научной деятельности: системы технического диагностирования узлов трения, контроль и прогнозирование технического состояния.

Количество публикаций: 56.

E-mail: Angelik2003@ukr.net 
